\title{
Polyphenol- and anthocyanin content changes effected by different fermentation- pressing and aging technologies
}

\author{
Horváth, ${ }^{1 *}$ E., Kocsis, ${ }^{1}$ L. \& Bakó, ${ }^{1}$ A. \\ ${ }^{1}$ University of Pannonia Georgikon Faculty Department of Horticulture, 8360 Keszthely, Deák Ferenc str. 16., \\ Hungary;*edit.horvath@georgikon.hu
}

\begin{abstract}
Summary: Different grape processing, fermentation and aging technologies were compared in our study on the white wine-grape variety Grüner Veltliner between 2012 and 2014 in Hungary,Cserszegtomaj. The vines are grown on brown forest soil on dolomite bedrock, stocks were planted $3 \times 1 \mathrm{~m}$ row and vine space, respectively in our experimental area. The soil has slightly alkaline $\mathrm{pH}$, the orientation of the vine rows are East-West. The training system is modified Guyot cordon, with $1 \mathrm{~m}$ trunk height and cane pruning method. After the harvest half of the yield has been put into the de-stemmer crusher before pressing while the other half has been pressed immediately (whole bunches). From the filtered and bottled wine anthocyanin, and polyphenol content was measured in 2013 and 2014. Another enological technology testing experiment has been set on aging of Grüner Veltliner in 2013. The wine was fermented with addition of fine lees from juice sedimentation. Traditional (racking only), battonage and fast ready-made aging technologies have been set together, each treatment in three replicates were observed.
\end{abstract}

Keywords: wine, processing, fermentation, chemical analysis, oeno-technology

\section{Introduction}

Vitis vinifera $\mathrm{cv}$ Grüner Veltliner easily can be used for experimenting because it is highly productive, midseasonal, frost tolerant and does not rot fast. Wine can be easily produced with classical white wine technology is also a big advantage to make easy-drinking fresh wine. By low crop load technology- we can produce juicy, mineral white wine. The whole Hungarian production area of the 'Grüner Veltliner' is 1325 hectares. Most of the plantations belong to the wine region of Balatonboglár. In addition this is the most important white wine grape variety in the wine region of Sopron planted on 85 hectares. 'Grüner Veltliner' has been cultivated since the roman times in Austria where the third of the country's vineyards is covered by this grape variety (Regner et al., 2009, Pavalescu et al., 2012).

In our study different grape processing, fermentation and aging technologies were compared on the well known white wine-grape variety Grüner Veltliner between 2012 and 2014 in Hungary. Our aim is to find the best grape processing and ageing technology for this variety.

\section{Materials and methods}

Our experimental area is located in Cserszegtomaj, Hungary. The vines are grown on brown forest soil on dolomite bedrock, stocks were planted $3 \times 1 \mathrm{~m}$ row and vine space, respectively. The soil has slightly alkaline $\mathrm{pH}$, the orientation of the vine rows is East-West. The training system is modified Guyot cordon, with $1 \mathrm{~m}$ trunk height and cane pruning method. Grapes were harvested at 24 Brix and 6,5 g/l total titratable acid content on 24th September 2012. After the harvest half of the yield has been put into the destemmer crusher before pressing while the other half has been pressed immediately (whole bunches). Each processing method's product was partitioned again; $75 \%$ have been left to sediment for 24 hours the other $25 \%$ continued its way to the fermentation. From the $75 \%$ sediment must $25 \%$ have been fermented on fine lees, $25 \%$ have been fermented without addition of fine lees, nutrients or yeast and to the last $25 \%$ of the must yeast (Fermicru 4F9) and $20 \mathrm{~g} / \mathrm{l}$ of nutrients were added. Each treatment in three replicates was observed. From the filtered and bottled wine colour, polyphenol- and calcium content was measured in 2013.

3 repetition of every type of wine were examined:

1. Crushed, not left on sediment

2. Crushed, fermented on fine lees

3. Crushed, fermented without fine lees

4. Crushed, fermented without fine lees and yeast added

5. Whole bunch pressing, not left on sediment

6. Whole bunch pressing, fermented on fine lees

7. Whole bunch pressing, fermented without fine lees

8. Whole bunch pressing, fermented without fine lees and yeast added

Another enological technology testing experiment has been set on ageing of Grüner Veltliner in 2013. The grape's acidity was $7.5 \mathrm{~g} / \mathrm{l}$, its must degree was 20 Brix as harvested, which was chaptalized to 21,2 Brix and fermented with addition of fine lees from juice 
sedimentation. have been set together, each treatment in three replicates were observed. Clarification was carried out by bentogran, silicic acid and gelatin in all cases but different times for the differently aged wines. Colour, polyphenol and titratable acid contents were measured the same way as in the first experiment.

\section{Measurement of the total polyphenols}

The Folin-Ciocalteu reagent (FCR) or Folin's phenol reagent or Folin-Denis reagent is a mixture of phosphomolybdate (H3PMo12O40) and phosphotungstate (H3PW12O40) used for the colorimetric in vitro assay of phenolic and polyphenolic antioxidants. After the reagent oxidizes all the phenolic compounds it is reduced to tungsten oxide (Mo8023) and to blue wolfram oxide (W8O23). The absorbance maximum of this color is on $750 \mathrm{~nm}$ which value is proportional to the phenol compounds including in the wine.

The next protocol have been followed according to all the samples:

- $1 \mathrm{ml}$ wine

- $50 \mathrm{ml}$ distillated water

- $5 \mathrm{ml}$ Folin-Ciocalteu reagent

- $20 \mathrm{ml} \mathrm{Na} \mathrm{CO}_{3}$ solution

After mixing the above mentioned ingredients we filled the flask to the $100 \mathrm{ml}$ sign with distilled water. The solution was homogenized and incubated at room temperature for 30 minutes to stabilize the color of the sample. It was measured by spectrophotometer on $750 \mathrm{~nm}$ on $1 \mathrm{~cm}$ length. Sample blank was the absorbance of distilled water.

\section{Measurement of the anthocyanin}

Anthocyanins are odorless and nearly flavorless watersoluble vacuolar pigments that may appear red, purple, or blue. They belong to the flavonoids synthesized via the phenylpropanoid pathway; they are, contributing to taste as a moderately astringent sensation. Because of their antioxidant effect their presence is important according to oenology. Anthocyanins readily polymerize with tannins, they play an important role in tannin retention and in aging. There is a close association between anthocyanins and wine color.

This method measures the ionized and ionizables anthocyans.

- Sample: $100 \mu \mathrm{l}$ of wine $+2000 \mu \mathrm{l}$ of chromogen reagent (KCLG buffer $\sim 0,6$; ethanol $<12 \%$; stabilizer)

- Sample blank: $100 \mu \mathrm{l}$ of distilled water $+2000 \mu \mathrm{l}$ of chromogen reagent

After the mixing of the solution it has to be incubated at room temperature $\left(+15-25^{\circ} \mathrm{C}\right)$ for 5 minutes. The measurement was carried out on $520 \mathrm{~nm}$ wavelength on $1 \mathrm{~cm}$ lightpath against distilled water.

\section{Calculation of the polyphenol content}

The polyphenol content was calculated by the following equation:

$$
\text { Sabs } * 20=\text { Folin index }
$$

\section{Calculation of the anthocyanin content}

The anthocyanin content was calculated by the following equation:

$$
\begin{gathered}
(\text { Sabs }- \text { Sample blank abs }) * 525= \\
\text { Anthocyanin content }[\mathrm{mg} / \mathrm{l}]
\end{gathered}
$$

\section{Results}

Colour pigments are not characteristics of white vines, but using different technologies of grape processing could result differences in the wine (Table 1). Grape crushing resulted higher anthocyanin content than the whole bunch pressing by 5 to closely 20 times differences were measured. The Folin index was variable by treatments as the indicator of total polyphenols content. In general crushing resulted higher polyphenols content according to our measurements. The highest polyphenols content in average (14.1 Folin index) was measured from the first crushed and after pressed grape and fermented without fine lees and yeast was added additionally (treatment 4C). The whole bunch pressing resulted 4-6 times lower Folin index independently from the fermentation.

Table 1. Anthocyanin and polyphenol content of the wines in the first survey

\begin{tabular}{|l|c|c|}
\hline & $\begin{array}{c}\text { Anthocyanin } \\
\text { content [mg/l }\end{array}$ & $\begin{array}{c}\text { Folin } \\
\text { index }\end{array}$ \\
\hline 1/A & 7.03 & 9.29 \\
\hline 1/B & 7.82 & 9.00 \\
\hline 1/C & 12.44 & 13.21 \\
\hline 2/B & 12.49 & 12.61 \\
\hline 2/C & 11.86 & 14.70 \\
\hline 3/A & 1.89 & 12.41 \\
\hline 3/B & 3.36 & 10.94 \\
\hline 4/C & 4.09 & 14.10 \\
\hline 5/A & 4.30 & 13.32 \\
\hline 5/C & 3.46 & 13.75 \\
\hline 6/A & 2.62 & 1.40 \\
\hline 6/B & 1.05 & 2.42 \\
\hline 6/C & 2.60 & 2.12 \\
\hline 7/A & 1.05 & 2.15 \\
\hline 7/B & 1.76 & 2.35 \\
\hline 7/C & 0.70 & 1.88 \\
\hline 8/A & 0.70 & 2.48 \\
\hline 8/B & 0.52 & 2.30 \\
\hline 8/C & 0.95 & 2.34 \\
\hline
\end{tabular}

1. A-B-C Crushed, not left on sediment

2. B-C Crushed, fermented on fine lees

3. A-B Crushed, fermented without fine lees

4. C Crushed, fermented without fine lees and yeast added

5. A-C Whole bunch pressing, not left on sediment

6. A-B-C Whole bunch pressing, fermented on fine lees

7. A-B-C Whole bunch pressing, fermented without fine lees

8. A-B-C Whole bunch pressing, fermented without fine lees and yeast added

The ageing treatments resulted less variability among the three treatments than grape processing did. The anthocyanin content was no detectable in 5 samples (Table 2), in all samples form battonage and in two of fast ready ageing technology was applied. The Folin index was less variable either among ageing treatment than in the grape processing 
and fermentation treatment (Table1 and Table 2). The Folin index varies between 1.306 to 2.106 , which is very similar to the whole bunch pressed processing and fermentation on sediments (1.40 to 2.48 ).

As the result of the second experiments' organoleptic evaluation concluded that the battonage wines are the mostly prefered ones by the jury. The second best average points belong to the standard technology wine. The quick-aged wines were less liked.

Table 2 Anthocyanin and polyphenol content of the wines in the second survey

\begin{tabular}{|c|c|c|}
\hline & $\begin{array}{c}\text { Anthocyanin } \\
\text { content [mg/l] }\end{array}$ & $\begin{array}{c}\text { Folin } \\
\text { index }\end{array}$ \\
\hline 1/A & n.d & 1.686 \\
\hline 1/B & 2.625 & 1.753 \\
\hline 1/C & 2.625 & 1.900 \\
\hline 2/A & n.d & 1.306 \\
\hline 2/B & n.d & 2.106 \\
\hline 2/C & n.d & 2.093 \\
\hline 3/A & n.d & 1.740 \\
\hline 3/B & n.d & 1.493 \\
\hline 3/C & $\mathbf{1 . 5 7 5}$ & 1.686 \\
\hline
\end{tabular}

1 A-B-C Traditional (racking only),

2 A-B-C Battonage,

3 A-B-C Fast ready-made, ageing technologies.

\section{Discussion}

Total and individual anthocyanins, and proanthocyanidin fraction contents can be measured in red and white wines from grapes (Sanchez-Moreno et al., 2003). Anthocyanin presence in phenolic polymers will affect wine attributes, among them color, astringency, fining, because of greater retention of tannin in their presence (Singleton \& Trousdale 1992). From our results we can conclude that processing of grapes like crushing or pressing the whole bunch has greater effect of both of the anthocyanin content and of the polyphenols content than did ageing process. It could be because seed polyphenols could be solved in the wine and the crushing resulted therefore higher amount of polyphenols. This result is also explains with Singleton and Trousdale (1992) findings, that seed tannin is soluble in white wine but is not retained in the face of fermentation levels of grape and yeast solids unless accompanied by anthocyanins as in red wines. The grape ripeness also could contribute to the polyphenols contents of the white wines as the results of Nyitrainé Sárdy et al. (2010) show in case of resistant grape varieties.

\section{References}

Nyitrainé Sárdy D., Kállay M. \& Májer J. (2010): Rezisztens szőlőfajták polifenol tartalmának vizsgálata az érés során. Kertgazdaság. 38: 46-55.

Pavelescu, D., Fiechter, G., Steidl, R., Eder, R. \& Kneifel, W. (2012): Sensory and chemical characteristics of wines from the variety 'Grüner Veltliner' in connection with the sur lie method. Mitteilungen Klosterneuburg, Rebe und Wein, Obstbau und Früchteverwertung. 62: 21-30.

Regner, F., Hack, R., Hanak K. \& Santiago, J.L. (2009): The variability within the cultivar Grüner Veltliner under different aspects. Acta Horticulturae. 827: 245-252.

Sánchez-Moreno, C., Cao, G., Ou, B. \& Prior, R. L. (2003): Anthocyanin and Proanthocyanidin Content in Selected White and Red Wines. Oxygen Radical Absorbance Capacity Comparison with Nontraditional Wines Obtained from Highbush Blueberry. J. Agric. Food Chem., 51: 4889-4896.

Singleton, V. L. \& Trousdale, E. K. (1992): Anthocyanin-tannin interactions explaining differences in polymeric phenols between white and red wines. American Journal of Enology and Viticulture. 43: 63-70. 